Davis, C. M., J. A. Heath, and C. J. W. McClure. 2017. Nest box use by American Kestrels and other cavity-nesting birds during the nonbreeding season. Avian Conservation and Ecology 12(2):5. https://doi.org/10.5751/ACE-01044-120205

Copyright (C) 2017 by the author(s). Published here under license by the Resilience Alliance.

Short Communication

\title{
Nest box use by American Kestrels and other cavity-nesting birds during the nonbreeding season
}

\author{
Caitlin M. Davis ${ }^{1}$, Julie A. Heath ${ }^{1}$ and Christopher J. W. McClure ${ }^{2}$ \\ ${ }^{1}$ Boise State University Department of Biological Sciences and Raptor Research Center, ${ }^{2}$ The Peregrine Fund
}

\begin{abstract}
Nest boxes are posted to provide breeding sites for cavity-nesting birds but less is known about their function in the nonbreeding season, when nest boxes may become important roost sites. In winter months, we surveyed 79 nest boxes before dawn for roosting American Kestrels (Falco sparverius) and other cavity-nesting birds in southwestern Idaho and we reviewed camera recordings from the entire nonbreeding season at a nest box within the study site to better understand nest box use in the nonbreeding season. During surveys we found seven American Kestrels roosting in six nest boxes, Northern Flickers (Colaptes auratus) in 16 nest boxes and a European Starling (Sturnus vulgaris) in one nest box. Video recordings revealed inter- and intra-specific conflicts within the nest box as well as a positive relationship between the length of night and the time spent roosting in the box. These results suggest that cavitynesting birds in our study area are likely to seek out and compete for nest boxes to use as roost sites in the nonbreeding season and the effects of nest boxes on the nonbreeding season ecology of birds should be considered.
\end{abstract}

\section{Utilisation de nichoirs par les Crécerelles d'Amérique et d'autres nicheurs cavicoles en dehors de la saison de nidification}

RÉSUMÉ. Les nichoirs sont installés afin de fournir des sites de nidification aux oiseaux nicheurs cavicoles; or, on en connait peu sur leur fonction en dehors de la saison de nidification, quand ils servent alors peut-être de dortoirs. Pendant les mois d'hiver, nous avons examiné 79 nichoirs avant l'aube à la recherche de Crécerelles d'Amérique (Falco sparverius) et d'autres nicheurs cavicoles dans le sudouest de l'Idaho. Nous avons aussi visionné les vidéos prises à un nichoir dans l'aire d'étude durant l'entièreté de la saison hors nidification afin de mieux comprendre l'utilisation des nichoirs à cette saison. Nous avons trouvé sept crécerelles dormant dans six nichoirs, des Pics flamboyants (Colaptes auratus) dans 16 nichoirs et un Étourneau sansonnet (Sturnus vulgaris) dans un autre nichoir. Les bandes vidéos ont révélé des conflits inter et intra-spécifiques dans le nichoir ainsi qu'une relation positive entre la longueur de la nuit et le temps passé à dormir dans le nichoir. Nos résultats indiquent que les nicheurs cavicoles de notre aire d'étude recherchent vraisemblablement les nichoirs et se font concurrence pour ceux-ci afin de les utiliser comme dortoir en dehors de la saison de nidification; nous pensons que les effets des nichoirs sur l'écologie des oiseaux hors saison de nidification devraient être pris en compte.

Key Words: cavity nester; Colaptes auratus; competition; Falco sparverius; nest box; roost

\section{INTRODUCTION}

Protected roost sites, e.g., dense vegetation or cavities, are critical to the survival of many birds wintering in temperate climates because they can alleviate metabolic pressures brought on by lower temperatures, extreme weather, and limited food (Walsberg 1986, Cooper 1999, McCafferty et al. 2001). Roosting in closed sites such as cavities in winter provides more thermal benefits (Kendeigh 1961, Cooper 1999) and better protection from predators (Sunde et al. 2003, Bock et al. 2013) than roosting in open sites such as tree limbs. This is most likely why cavity-nesting species will use cavities as roosts in the nonbreeding season and preferentially choose them during winter months (Duguay et al. 1997, Mainwaring 2011, Bock et al. 2013). In human-altered landscapes where natural tree cavities may be limited, some secondary cavity nesting species use other available closed roost sites such as human-made structures, e.g. barns, sheds, or abandoned buildings, and nest boxes as roosts in the nonbreeding season (Mainwaring 2011). Therefore, although nest boxes are typically posted to increase breeding productivity, nest boxes may also create important roost sites that lead to improved overwintering survival and beneficial population-level effects.

The effectiveness of nest box programs as a management tool typically requires that nest boxes either decrease nest site limitation or create improved productivity relative to natural cavities (McClure et al. 2017a). Without careful placement, nest boxes may become ecological traps (Strasser and Heath 2013). For example, nest boxes provide similar thermal benefits as natural cavities when temperatures are above freezing (Kendeigh 1961, Grüebler et al. 2014). However, when temperatures drop below freezing, natural cavities may better buffer extreme ambient temperatures and have significantly greater thermal benefits compared to artificial cavities (McComb and Noble 1981, Grüebler et al. 2014). The suitability of nest boxes as winter roosts is therefore unclear. Thus, it is important to explore the use of nest boxes in the nonbreeding season to reveal whether cavitynesting birds use nest boxes as roosts. 
American Kestrels (Falco sparverius) are small, cavity-nesting falcons that are widespread across North and South America. Kestrels readily use nest boxes for breeding and nest box programs are common throughout their range (Smallwood and Bird 2002). In response to observed declines in populations across much of North America, McClure et al. (2017b) recently called for research into the nonbreeding ecology of American Kestrels. Kestrel roosting behavior during the nonbreeding season seems to be variable across the species' range and their use of nest boxes as roosts is not well known. In winter, without the presence of nest boxes, Kestrels have been documented roosting in human-made structures in Ohio (Mills 1975) and Louisiana (Doody 1994), and in one communal tree roost in California (Miller and Lanzone 2015). Additionally, Kestrels used spruce trees as roosts while migrating through Saskatchewan (Bortolotti and Wiebe 1993). In Pennsylvania, where established nest boxes were available, Kestrels were not observed using boxes to roost and used other human-made structures (Ardia 2001). However, during one winter in Missouri, female Kestrels roosted in all 50 nest boxes in the study area (Toland and Elder 1987), which is, to our knowledge, the only known documentation of this behavior. These behavioral differences raise questions about the suitability of nest boxes as winter roosts and why Kestrels used them in one location, but not the other. Here, we examine the use of nest boxes by Kestrels during the nonbreeding season in relation to seasonality, day length, and heterospecifics in our study site in southwestern Idaho. We predicted that Kestrels will be more likely to roost in nest boxes during periods of low minimum temperatures, and will remain in roosts longer as day length increases. Additionally, we predicted that there is inter- and intraspecific competition for nest boxes as roosts during the nonbreeding season.

\section{METHODS}

Breeding American Kestrels in southwestern Idaho $\left(43^{\circ} \mathrm{N} 116^{\circ}\right.$ W) have been closely monitored through the use of established nest boxes for over 25 years (Steenhof and Peterson 2009) yet no studies have examined their roosting behavior during the nonbreeding season. At this study site, Kestrel pairs initiate egglaying from mid-March through mid-July, so we considered the nonbreeding season to be mid-July through mid-March. Our study area is over $1000 \mathrm{~km}^{2}$ and in a human-altered landscape consisting of suburban, agricultural, and shrub-steppe covertypes. There is an abundance of human-made structures as well as interspersed patches of trees available for roosting. In January 2015, we blocked the entrance to the nest box and visually inspected 79 nest boxes in the study area between 05:00 and sunrise. If a Kestrel was inside the nest box, we caught the bird by hand and read the band or marked it with an aluminum U.S. Geological Service band and an alphanumeric color band, and returned it to the nest box. If another species was in the box, the bird was left in the box with the lid closed and the plug removed. All methods and protocols described above were approved by the Boise State University IACUC review board (IACUC Approval Number 006-AC14-024).

We also video-recorded the activity in a nest box installed on the roof of the research library at the campus of the World Center for Birds of Prey in Boise, Idaho that was within the study site.
We recorded videos using the KestrelCam (BOSCH Flexidome NDI-50022-V3, McClure et al. 2015). The nest box was modified to include an opaque window on one side to improve lighting for the KestrelCam. The KestrelCam recorded 20 seconds of video anytime it sensed movement between 22 July 2014 and 11 March 2015. The KestrelCam was equipped with an infra-red light and had the ability to sense movement and record at night. We reviewed all videos and recorded the species, the activity of individuals, and the duration of the nest box visit. We considered visits that lasted $>8$ hours and overlapped the dark part of the day to be roosting events. For each roosting event, we recorded the entry and exit times.

We obtained the nightly minimum temperature at the weather station located at the Boise Airport (5.6 km from the KestrelCam nest box) from the U.S. National Oceanic and Atmospheric Administration's website (https://www.ncdc.noaa.gov/). We then examined whether time spent in the nest box per night was correlated with the length of the night using linear regression, and whether the probability of a Kestrel roosting in the box was correlated with minimum temperature using logistic regression. All analyses were performed using R (R Development Core Team 2016).

\section{RESULTS}

We found seven American Kestrels roosting in six of the 79 boxes, including 4 lone females, 1 lone male, and 1 male and female pair. In 16 of the nest boxes we found lone roosting Northern Flickers (Colaptes auratus) and in 1 box, a single European Starling (Sturnus vulgaris). The remaining 56 boxes were empty.

The KestrelCam captured 722 videos of American Kestrels, 122 videos of Northern Flickers, six of Black-billed Magpies (Pica hudsonia), and two of European Starlings. Birds entered the nest box during the day and during the night. At 17:22 on 22 October 2014, we recorded an aggressive encounter between a male American Kestrel and a Black-billed Magpie with the Kestrel in the box and the magpie outside pecking inwards. We also recorded three aggressive encounters between Northern Flickers and American Kestrels, the most aggressive of which (see Videos) occurred at 12:40 on 11 October involving a male Kestrel jumping on the back of a male Flicker with the flicker eventually escaping the box. Another encounter between a Flicker and a Kestrel occurred at 18:45 on 21 October and involved a female Kestrel initially perched outside of the entrance but leaving after being pecked by a male flicker inside the box. And, at 8:27 on 21 February a male Kestrel inside the box displaced a male Flicker that was perched outside the entrance.

There were 55 videos showing two Kestrels inside of the box, all of which where the sex of both birds could be determined involved a male and a female. Though females were observed entering the KestrelCam nest box for short periods of time, they never remained in the box for the duration of the night. A notable sequence of videos occurred beginning at 17:22 on 31 December, which showed periods of peace and aggression between two Kestrels, with the male mostly being the aggressor (see Videos). Fifteen of $17(88 \%)$ days in which there were videos of males and females together occurred after 1 February and those videos mostly showed a male performing a courtship display to a female within the nest box. 
Another interesting event occurred 18 November beginning at 05:02 and again at 07:47 (see Videos) when primary and rectricial feathers of a male Kestrel were frozen to the floor of the KestrelCam nest box. The bird can be seen struggling to free his feathers, eventually loosening them from the nest box, and ultimately surviving the ordeal. The low temperature on that night was -16 degrees Celsius, lower than typical minimum temperatures for this region.

American Kestrels visited the KestrelCam box on $58 \%$ of the days during the recording period, whereas Northern Flickers visited the box on $8 \%$ (Fig. 1). American Kestrels appeared to visit the KestrelCam box mostly during two periods: late October through early January and February through the end of the survey period, corresponding with the courtship period (Fig. 1). Although several species visited the KestrelCam nest box over the course of the study, only male American Kestrels were observed roosting in the box overnight. We recorded American Kestrels roosting on 48 occasions between 23 October and 2 February (Fig. 1). There were four roost occasions for which we could not determine entry time. On average, Kestrels entered the box to roost 2.37 (SD = 27.46) minutes after sunset and exited the box $4.83(\mathrm{SD}=75.10)$ minutes after sunrise. The length of a roosting occasion increased over the course of the study in concert with the length of night $\left(\mathrm{R}^{2}=0.27\right.$; Fig. 2). Additionally, from 233 days of observations we found that the probability of a Kestrel roosting in the KestrelCam nest box increased significantly $(\beta=-0.01, \mathrm{SE}=$ $0.002, \mathrm{p}<0.001)$ as daily minimum temperature decreased.

Fig. 1. Timeline indicating days when (A) American Kestrels (Falco sparverius) and (B) Northern Flickers (Colaptes auratus) were observed visiting in daylight (black bars) or roosting overnight (gray bars) in a nest box at the World Center for Birds of Prey in Boise, Idaho.
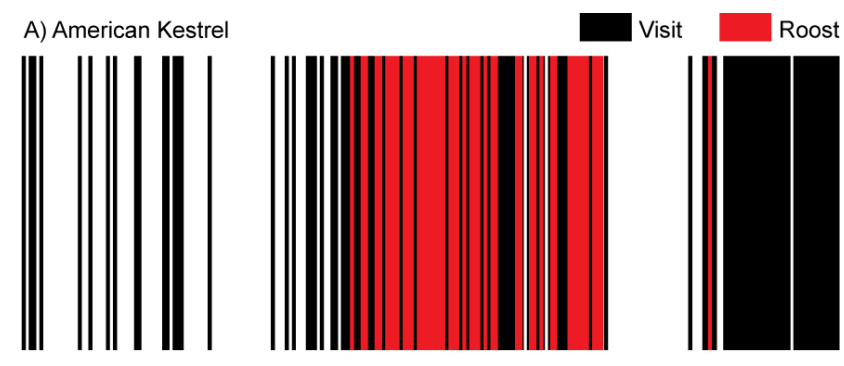

B) Northern Flicker

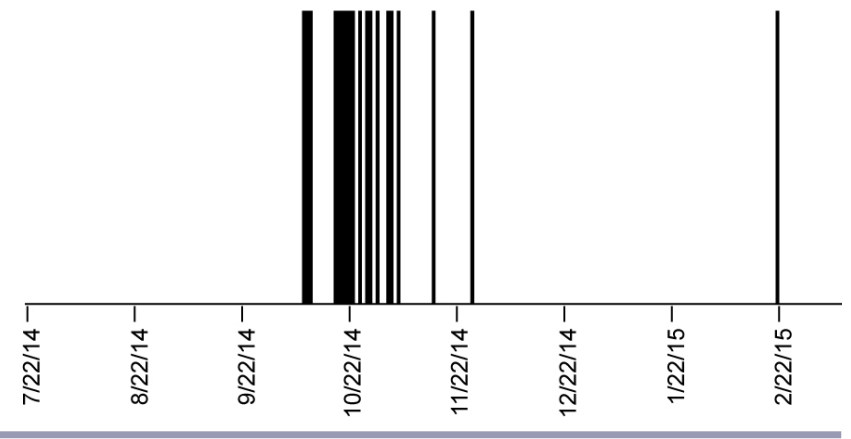

Fig. 2. Number of hours spent roosting per night by American Kestrels (Falco sparverius) in a nest box at the World Center for Birds of Prey in Boise, Idaho and the number of hours in a given night.

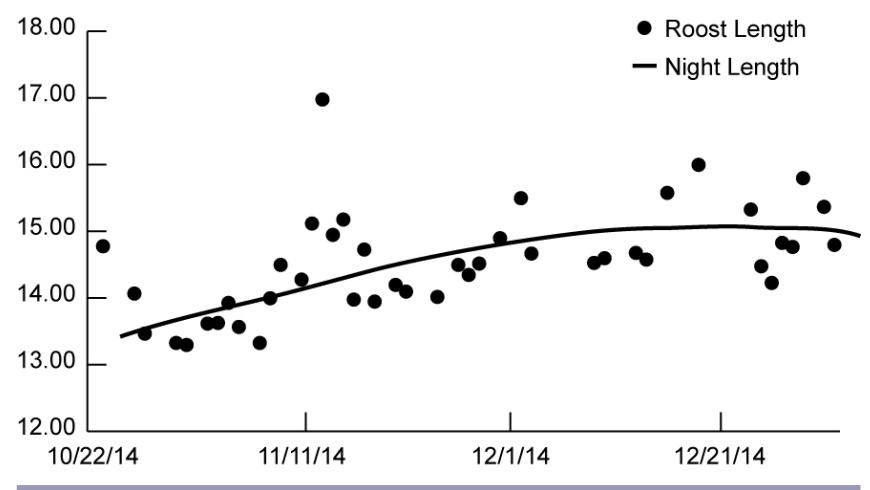

\section{DISCUSSION}

We found that American Kestrels and other cavity-nesting birds used nest boxes during the nonbreeding season. Further, conspecific interactions within nest boxes may be a part of pair formation or, perhaps, a strategy for thermoregulation when roosting. Interspecific interactions recorded at one nest box over the course of the nonbreeding season suggest that there may be competition for at least some nest boxes. Although thought of as a habitat enhancement for breeding, nest boxes clearly provide important resources for roosting and early breeding season displays.

Daytime surveys of Kestrels in the study area suggest that Kestrel density $\left(\sim 0.5\right.$ Kestrels per $\left.\mathrm{km}^{2}\right)$ is much higher than the rate of occupied nest boxes (Heath, unpublished data) and some nest boxes were not used as roosts. These results are similar to the findings of Ardia (2001), where nest boxes were available in Kestrel territories during winter but not used by Kestrels. However, we only surveyed nest boxes during a short period (20 days) within one season and data, though limited, from the KestrelCam suggested that the probability of occupancy increased as minimum temperatures decreased. Thus, patterns of roosting can vary within a season. Alternatively, Kestrels may not have used some boxes because other roosts within occupied territories provided more thermal benefits. Though nest boxes provide thermoregulatory savings in winter, their low buffering capacity at low ambient temperatures might be less desirable to wintering birds (Grüebler et al. 2014). In addition, differences in the structural characteristics and location of nest boxes can greatly alter microclimate (Mainwaring 2011). The boxes in the area are positioned and designed to provide a favorable microclimate during the breeding season but some may not provide ample benefits during winter months. Indeed, the video recorded by the KestrelCam of the male Kestrel with its feathers apparently frozen to the floor of the nest box suggests a unique hazard to birds during the winter (see Videos). In addition, following some relatively cold winters, we have found American Kestrels that appeared to die of exposure during early March nest box visits (Heath, unpublished data). Thus, whether nest boxes 
may act as an ecological trap by attracting cavity nesters to roosts that do not have the thermoregulatory benefits of natural cavities warrants further investigation.

The observation of a male and female roosting together in a nest box is contrary to the general description of behavior of American Kestrels in the nonbreeding season, when they are known to be territorial toward conspecifics (Cade 1955, Mills 1976). However, in areas with resident pairs, male and female Kestrels may retain pair bonds throughout the year (Heath, unpublished data) or pairs may have tolerated each other when food resources were particularly high. That resource levels might mediate competition between conspecifics is supported by documentation that Kestrels will sometimes tolerate familiar conspecifics during the day (Doody 1994) and will occupy a communal roost in a grove of trees when it is beneficial in the local habitat (Miller and Lanzone 2015). Communal roosting may also have been observed because increased thermal benefits were sought. Roosting together in a cavity provides substantial thermal benefits for both individuals because of metabolic heating (Cooper 1999, Grüebler et al. 2014). Pairs roosting together in cavities may be more common than we previously thought, however, the aggressive encounter between a male and female within the KestrelCam nest box suggests that attempts to share roost sites are not always without conflict.

Our results also suggest that Kestrels will remain in roosts for longer periods as the length of night increases (Fig. 2) and that Kestrels are more likely to use nest boxes on colder nights. Nightlength is known to affect weight and metabolism of birds (Lehikoinen 1987, Haftorn 1989) and it is intuitive that Kestrels would remain roosting during night when temperatures are low. That Kestrels generally enter and leave the roost in concert with sunset and sunrise, respectively, suggests that roosting behavior of Kestrels might not severely hamper the interpretation of data from geolocators, as has been demonstrated in other species (Gow 2016). It would be interesting to compare roosting behavior of Kestrels to other sites with warmer minimum temperatures or communities of cavity-nesting birds to compare the relative importance of nest boxes for nonbreeding season resources.

More information is needed on the seasonal and year-to-year variation in roosting behavior across the range of American Kestrels to understand the mechanisms involved in nonbreeding season roost selection. If nest boxes are introduced in efforts to boost breeding populations of a particular species, consideration of nonbreeding season use may be important to encourage extra attention to the construction and maintenance of nest boxes over the whole year.

Responses to this article can be read online at: http://www.ace-eco.org/issues/responses.php/1044

\section{Acknowledgments:}

We would like to thank Michael Henderson and Hannah Brown for assisting with nighttime surveys. This research was supported by an award from the National Science Foundation (DEB 1145552), a Boise State Provost's Office Work Study Award, Boise State University's Department of Biological Sciences and Raptor
Research Center, and American Kestrel Adopt-a-box sponsors. We also thank Ms. Judith King and Lynn and Jack Loacker for funding. We thank Bosch and Matt Thomas of New/Era Sales, Inc. for donating the KestrelCam. We also thank The Peregrine Fund's research library for help in obtaining literature, Delora Hilleary for reviewing videos from the KestrelCam, and Amy Siedenstrang for help in making figures.

\section{LITERATURE CITED}

Ardia, D. R. 2001. Winter roosting behavior of American Kestrels. Journal of Raptor Research. 35:58-61.

Bock, A., B. Naef-Daenzer, H. Keil, F. Korner-Nievergelt, M. Perrig, and M. U. Grüebler. 2013. Roost site selection by Little Owls Athene noctua in relation to environmental conditions and life-history stages. Ibis 155:847-856. http://dx.doi.org/10.1111/ ibi. 12081

Bortolotti, G. R., and K. L. Wiebe. 1993. Roosting American Kestrels (Falco sparverius) during migration in Saskatchewan. Journal of Raptor Research 27:47-49.

Cade, T. J. 1955. Experiments on winter territoriality of American Kestrel, Falco sparverius. Wilson Bulletin 67:5-17.

Cooper, S. J. 1999. The thermal and energetic significance of cavity roosting in Mountain Chickadees and Juniper Titmice. Condor 101:863-866. http://dx.doi.org/10.2307/1370077

Doody, J. S. 1994. Winter roost-site use by female American Kestrels (Falco sparverius) in Louisiana. Journal of Raptor Research 28:9-12.

Duguay, A., G. Ritchison, and P. Duguay. 1997. The winter roosting behavior of Eastern Screech-Owls in Central Kentucky. Journal of Raptor Research 31:260-266.

Gow, E. A. 2016. Analyzing geolocator data for birds that roost in cavities year-round. Journal of Field Ornithology 87:74-83. http://dx.doi.org/10.1111/jofo. 12130

Grüebler, M. U., S. Widmer, F. Korner-Nievergelt, and B. NaefDaenzer. 2014. Temperature characteristics of winter roost-sites for birds and mammals: tree cavities and anthropogenic alternatives. International Journal of Biometeology 58:629-637. http://dx.doi.org/10.1007/s00484-013-0643-1

Haftorn, S. 1989. Seasonal and diurnal body weight variations in titmice, based on analyses of individual birds. Wilson Bulletin 101:217-235.

Kendeigh, S. C. 1961. Energy of birds conserved by roosting in cavities. Wilson Bulletin 73:140-147.

Lehikoinen, E. 1987. Seasonality of the daily weight cycle in wintering passerines and its consequences. Ornis Scandinavica 18:216-226. http://dx.doi.org/10.2307/3676769

Mainwaring, M. C. 2011. The use of nest boxes by roosting birds during the non-breeding season: a review of the costs and benefits. Ardea 99:167-176. http://dx.doi.org/10.5253/078.099.0206

McCafferty, D. J., J. B. Moncrieff, and I. R. Taylor. 2001. How much energy do Barn Owls (Tyto alba) save by roosting? Journal of Thermal Biology 26:193-203. http://dx.doi.org/10.1016/ S0306-4565(00)00042-5 
McClure, C. J. W., D. M. Hilleary, and D. P. Spurling. 2015. American Kestrels actively exclude European Starlings from using a nest box. Journal of Raptor Research 49:231-233. http:// dx.doi.org/10.3356/0892-1016-49.2.231

McClure C. J. W., B. P. Pauli, and J. A. Heath. 2017a. Simulations reveal the power and peril of artificial breeding sites for monitoring and managing animals. Ecological Applications 27 (4):1155-1166. http://dx.doi.org/10.1002/eap.1509

McClure, C. J. W., S. E. Schulwitz, R. Van Buskirk, B. P. Pauli, and J. A. Heath. 2017b. Research recommendations for understanding the decline of American Kestrels (Falco sparverius) across much of North America. Journal of Raptor Research, in press.

McComb, W. C., and R. E. Noble. 1981. Microclimates of nest boxes and natural cavities in bottomland hardwoods. Journal of Wildlife Management 45:284-289. http://dx.doi.org/10.2307/3807906

Miller, T. A., and M. J. Lanzone. 2015. Gregarious winter roosting and early morning perching behavior of American Kestrels (Falco sparverius) in the Imperial Valley, California. Journal of Raptor Research 49:526-528. http://dx.doi.org/10.3356/rapt-49-04-526-528.1

Mills, G. S. 1975. A winter population study of the American Kestrel in central Ohio. Wilson Bulletin 87:241-247.

Mills, G. S. 1976. American Kestrel sex ratios and habitat separation. Auk 93:740-748.

R Development Core Team. 2016. The R Project for Statistical Computing. R Foundation for Statistical Computing, Vienna, Austria.

Smallwood, J. A., and D. M. Bird. 2002. American Kestrel (Falco sparverius). In P. G. Rodewald, editor. The birds of North America. Cornell Lab of Ornithology, Ithaca, New York, USA. http://dx. doi.org/10.2173/bna.602

Steenhof, K., and B. E. Peterson. 2009. American Kestrel reproduction in southwestern Idaho: annual variation and longterm trends. Journal of Raptor Research. 43:283-290. http://dx. doi.org/10.3356/JRR-08-56.1

Strasser, E. H., and J. A. Heath. 2013. Reproductive failure of a human-tolerant species, the American Kestrel, is associated with stress and human disturbance. Journal of Applied Ecology 50:912-919. http://dx.doi.org/10.1111/1365-2664.12103

Sunde, P., M. S. Bølstad, and K. B. Desfor. 2003. Diurnal exposure as a risk sensitive behaviour in Tawny Owls Strix aluco? Journal of Avian Biology 34:409-418. http://dx.doi.org/10.1111/ j.0908-8857.2003.03105.x

Toland, B., and W. Elder. 1987. Influence of nest-box placement and density on abundance and productivity of American Kestrels in central Missouri. Wilson Bulletin 99:712-717.
Walsberg, G. E. 1986. Thermal consequences of roost-site selection: the relative importance of three modes of heat conservation. Auk 103:1-7.
Editor-in-Chief: Keith A.Hobson

Subject Editor: Jean-Pierre L.Savard
Sponsored by the Society of Canadian Ornithologists and Bird Studies Canada Parrainée par la Société des ornithologistes $d u$ Canada et Études d'oiseaux Canada

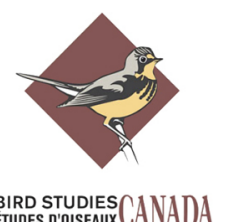

